\title{
Preparation and application of a novel monoclonal antibody specific for human B7-H3
}

\author{
JIAN SHI, DONG-LEI ZHANG, ZHI-CHU CUI and HUI-MIN WANG \\ Enzymology Laboratory, Affiliated Hospital of Nantong University, Nantong, Jiangsu 226000, P.R. China
}

Received September 30, 2014; Accepted November 30, 2015

DOI: $10.3892 / \mathrm{mmr} .2016 .5288$

\begin{abstract}
Human B7-H3 (CD276), as a new member of the B7 family has been demonstrated to mediate $\mathrm{T}$ cell proliferation and the production of interferon- $\gamma$. Two isoforms of B7-H3 have been identified in humans, $2 \operatorname{IgB} 7-\mathrm{H} 3$ and $4 \operatorname{IgB} 7-\mathrm{H} 3$. Since the costimulatory functions of the two isoforms remains to be fully elucidated, there are disagreements regarding their expression patterns as well as the $\mathrm{T}$ cell responses. In the present study, a single mouse anti-human monoclonal antibody (mAb), specific for 2IgB7-H3 and 4IgB7-H3 was established, termed 11F4. Using this antibody, the expression of B7-H3 was observed extensively in tumor cell lines, with the exception of certain human hematopoietic cell lines. Subsequently, the fusion proteins of the two $\mathrm{B} 7-\mathrm{H} 3$ isoforms were produced to analyze the biological function of 4IgB7-H3 and 2IgB7-H3 using a Cell Counting Kit-8 assay, and the data revealed that the two isoforms exhibited a similar function in promoting $\mathrm{T}$ cell proliferation. In addition, the effect of $\mathrm{B} 7-\mathrm{H} 3$ on the $\mathrm{T}$ cells was inhibited by the $11 \mathrm{~F} 4 \mathrm{mAb}$. Overall, the novel antibody produced was observed to exhibit an inhibitory effect offering a useful tool in further investigations of the function of B7-H3 isoforms.
\end{abstract}

\section{Introduction}

Complete activation of $\mathrm{T}$ cells in response to donor alloantigen presentation requires the delivery of two separate, but complimentary signals. One is delivered via the antigen-specific T-cell receptor, following recognition of an alloantigen in the context of a major histocompatibility complex molecule expressed on an antigen-presenting cell. The other is introduced by the costimulatory molecules, which result from the ligation of the costimulatory receptor-ligand pair to deliver a positive or negative activation signal (1). The T-cell

Correspondence to: Ms. Jian Shi, Enzymology Laboratory, Affiliated Hospital of Nantong University, 20 Xisi Road, Nantong, Jiangsu 226000, P.R. China

E-mail: jianshi_nantong@163.com

Key words: B7-H3, tumor cell lines, monoclonal antibody, $\mathrm{T}$ cell proliferation, block costimulatory molecules are predominantly comprised of the B7/CD28 superfamily and the tumor necrosis factor (TNF) family. In previous years, numerous members of the CD28 and B7 families have been identified, including programmed death-1 (PD-1), B and T lymphocyte attenuator, and the PD-L1, PD-L2, B7-H2, B7-H3 and B7-H4 ligands, which share similar protein domain structures consisting of one Ig-V-like domain and one Ig-C-like domain, which reside in the extracellular portion of the molecule (2-7).

B7-H3 is a novel member of the human B7 family, which shares 20-27\% amino acids with other B7 family members (5). Differential splicing of human B7-H3 leads to a 4Ig domain (VCVC) transcript (4IgB7-H3) and a 2Ig domain (containing $\mathrm{V} 1$ and $\mathrm{C} 2$ ) transcript (2IgB7-H3) (8). The $4 \mathrm{Ig}$ transcript is the dominant form in human tissues. By contrast, the mouse B7-H3 gene encodes only a single VC domain form of B7-H3. Human and mouse B7-H3 mRNAs are expressed broadly in lymphoid and non-lymphoid organs $(5,9)$. Soluble B7-H3-Ig binds to activated $\mathrm{T}$ cells, costimulating their proliferation and the production of interferon (IFN) $\gamma(5)$. However, several studies have indicated that B7-H3 has an inhibitory function. 2IgB7-H3 and 4IgB7-H3 have similar functions and can downregulate $\mathrm{T}$ cell responses $(10,11)$. Thus, further investigations are required to elucidate the contradictory results regarding the functions of B7-H3.

In order to analyze the expression pattern of B7-H3 at the protein level, and compare the biological function of the two B7-H3 isoforms, the present study generated one B7-H3 monoclonal antibody (mAb; clone $11 \mathrm{~F} 4$ ), which was able to recognize $2 \operatorname{IgB} 7-\mathrm{H} 3$ and $4 \operatorname{IgB} 7-\mathrm{H} 3$. The $11 \mathrm{~F} 4 \mathrm{mAb}$ was used to detect the expression of B7-H3 in tumor cell lines. The B7-H3 protein was expressed broadly on the surface of the tumor cells, with the exception of certain hematopoietic cell lines. Subsequently, the 2IgB7-H3 and 4IgB7-H3-Fc fusion protein was obtained using NIH3T3/2IgB7-H3, and the NIH3T3/4IgB-H3 stable expressing system was constructed. Notably, 2IgB7-H3 and 4IgB7-H3 exhibited a similar costimulatory function in promoting $\mathrm{T}$ cell proliferation. The $11 \mathrm{~F} 4$ $\mathrm{mAb}$ inhibited the positive effect activated by the B7-H3 fusion proteins.

\section{Materials and methods}

Preparation and culture of cells. The SP2/0 mouse myeloma cell line, NIH/3T3 mouse embryo fibroblast cell line, HEK293 
human embryonic kidney cell line, EAhy926 endothelial cell line, the human tumor cell lines (HO8910, H460, SKOV3, SW-1990, Patu8988, HepG2, MDA-MB-231, HeLa and MGC-803), the human malignant hematopoietic cell lines (Raji, Daudi, Jurkat, U266, U937, K562 and HL-60) and RPMI-8226) were obtained from American Type Culture Collection (Manassas, CA, USA). All the cell lines were cultured in RPMI-1640 medium (Gibco; Thermo Fisher Scientific, Inc., Waltham, MA, USA) or standard Dulbecco's modified Eagle's medium (DMEM; Gibco; Thermo Fisher Scientific, Inc.) supplemented with $10 \%$ fetal calf serum (FCS; GE Healthcare Life Sciences, Logan, UT, USA), 100 U/ml penicillin and $100 \mu \mathrm{g} / \mathrm{ml}$ streptomycin (Sigma-Aldrich, St. Louis, MO, USA) and $2 \mathrm{mM}$ L-glutamine (Sigma-Aldrich). The cells were cultured in a $5 \% \mathrm{CO}_{2}, 37^{\circ} \mathrm{C}$ incubator.

Animals and reagents. The present study was approved by the ethics committee of the Affiliated Hospital of Nantong University (Nantong, China). Female BALB/c mice (age, six weeks) were purchased from the Department of Experimental Animal (Shanghai Institute of Biological Products, Ministry of Health of China, Shanghai China). The three mice were housed together in an environment of $25^{\circ} \mathrm{C}$ with a natural light/dark cycle and food and water provided every day. A series of anti-human mAbs, including mouse monoclonal CD3 (clone UCHT1; 1:3,000; cat. no. ab119110) and mouse monoclonal IgG1 (1:3,000; cat. no. ab91353) were purchased from Abcam (Cambridge, MA, USA). Horseradish peroxidase (HRP)-conjugated goat anti-mouse IgG was purchased from Santa Cruz Biotechnology, Inc. (Dallas, Texas, USA; cat. no. sc-2031; 1:3,000). Functional CD28 monoclonal mouse antibody (1:1,000; cat. no. MAB342), and anti-His Tag mouse monoclonal antibody (1:1,000; cat. no. MAB050) were purchased from R\&D Systems, Inc. (Minneapolis, MN, USA).

Preparation of T cells and DCs. Peripheral blood mononuclear cells (PBMCs) were separated from $50 \mathrm{ml}$ healthy human peripheral blood (Nantong Central Blood Bank, Nantong, China) using Ficoll-Hypaque (TBD science, Tianjin, China) gradient centrifugation at $800 \mathrm{x} \mathrm{g}$ for $20 \mathrm{~min}$ at room temperature. Monocytes were prepared from the PBMCs by removing non-adherent cells to deplete the T cells, $\mathrm{B}$ cells and natural killer cells following $2 \mathrm{~h}$ incubation in 6-well culture plates at $37^{\circ} \mathrm{C}$. The $\mathrm{T}$ lymphocytes were isolated by classic erythrocyte-rosetting due to binding between sheep red blood cells and $\mathrm{T}$ lymphocytes $(12,13)$. The purity of the $\mathrm{T}$ lymphocytes was $>90 \%$. The adherent monocytes were cultured in RPMI-1640 medium containing 10\% FCS with human recombinant GM-CSF (500 U/ml; R\&D Systems, Inc.) and human recombinant IL-4 (200 U/ml; R\&D Systems, Inc.) to obtain monocyte-derived dendritic cells (mdDCs). Maturation of the mdDCs was achieved by incubating the cells with TNF- $\alpha$ (100 U/ml; R\&D Systems, Inc.) for $48 \mathrm{~h}$ at $37^{\circ} \mathrm{C}$.

Production of B7-H3 cDNA. Total RNA was prepared from the mdDCs using TRIzol reagent (Invitrogen; Thermo Fisher Scientific, Inc.) and was used for complementary DNA (cDNA) synthesis with a Superscript First-Strand Synthesis kit (Takara Bio, Inc., Dalian, China), according to the manufacturer's instructions. The genes encoding the extracellular domain of the two B7-H3 isoforms (accession number: NM_001024736 and accession number: NM_025240.2) were amplified from the pMD19-T/4IgB7-H3 and pMD19-T/2IgB7-H3 vectors using polymerase chain reaction (PCR) amplification with the following primers: B73b-A 5'-GCTAAGCTTCTGCGTCGG CGGGGCAGCCCT-3' (Hind III site shown in italics) and B73b-B 5'-CCTGGATCCTCAGGCTATTTCTTGTCCA-3' (BamH I site shown in italics) using Premix Taq ${ }^{\mathrm{TM}}$ (Takara Bio, Inc.). The thermocycling conditions were as follows: $3 \mathrm{~min}$ at $95^{\circ} \mathrm{C}$ for polymerase activation; followed by 35 cycles of denaturation at $95^{\circ} \mathrm{C}$ for $40 \mathrm{sec}$, annealing at $57^{\circ} \mathrm{C}$ for 45 sec, and extension at $72^{\circ} \mathrm{C}$ for $1 \mathrm{~min}$.

Expression of the 4IgB7-H3 and $2 \mathrm{IgB} 7-\mathrm{H} 3$ recombinant proteins. The 4IgB7-H3 and 2IgB7-H3 cDNA were subcloned into the pSectag2B mammalian expression vector (Invitrogen; Thermo Fisher Scientific, Inc.), which carries the C-terminal His-tag for purification and detection. The two types of cDNA were respectively introduced into NIH3T3 cells, which contain endogenous furin to cleave propeptide and release the mature metalloprotease (14), using Lipofectamine ${ }^{\mathrm{TM}} 2000$ (Invitrogen; Thermo Fisher Scientific, Inc.). The transfected cells were maintained in DMEM supplemented with $10 \%$ FCS, $100 \mathrm{U} / \mathrm{ml}$ penicillin, $100 \mu \mathrm{g} / \mathrm{ml}$ streptomycin and $2 \mathrm{mM}$ L-glutamine at $37^{\circ} \mathrm{C}$, with $95 \%$ air and $5 \% \mathrm{CO}_{2}$. Cells expressing the recombinant protein were selected in medium containing $400 \mu \mathrm{g} / \mathrm{ml}$ hygromycin-B (Invitrogen; Thermo Fisher Scientific, Inc.), in which cells expressing high levels of 4IgB7-H3 and 2IgB7-H3 were selected by single-cell cloning. The recombinant 4IgB7-H3 and 2IgB7-H3 was collected from the supernatant of the confluent cells grown in serum-free medium, and purified through the C-terminal His-tag using Protino Ni-NTA Agarose (Macherey-Nagel, Düren, Germany).

Generation and characterization of mouse anti-human B7-H3 $m A b s$. The six-week-old BALB/c mice were separately immunized with four injections of purified recombinant $4 \operatorname{IgB} 7-\mathrm{H} 3$ at 21-day intervals. The first three injections were $0.1 \mathrm{mg}$ subcutaneous injections and the fourth was a $0.05 \mathrm{mg}$ caudal vein injection. Subsequently, 4 days after the final injection, the immunized mice were sacrificed by cervical dislocation. The spleen cells were separated using a mesh screen. The splenocytes and murine myeloma SP2/0 cells were fused at a ratio of 10:1 by PEG4000 (Invitrogen; Thermo Fisher Scientific, Inc.) within $2 \mathrm{~min}$. The cells were subsequently cultured at $37^{\circ} \mathrm{C}$ in $5 \% \mathrm{CO}_{2}$. The procedure was conducted according to the method described by Groth and Scheidegger (15). Following 2 weeks of hypoxanthine-aminopterin-thymidine selection (Sigma-Aldrich), one hybridoma cell line secreting mouse anti-human B7-H3 mAb (11F4) was obtained, exhibiting high reactivity with recombinant 4IgB7-H3 using an enzyme linked immunosorbent assay (ELISA). The mAbs were purified on Protein G-Sepharose CL4B (Pharmacia, Uppsala, Sweden) affinity columns, and the Ig isotypes were identified using rapid test paper (Roche Diagnostics, Varilhes, France).

Binding assay. A 96-well plate (Corning Incorporated, Corning, NY, USA) was coated with recombinant 4IgB7-H3 or $2 \operatorname{IgB} 7-\mathrm{H} 3$ protein $(10 \mu \mathrm{g} / \mathrm{ml} ; 100 \mu \mathrm{l} / \mathrm{well})$ in 
$0.05 \mathrm{M}$ carbonate/bicarbonate buffer ( $\mathrm{pH}$ 9.6) overnight at $4^{\circ} \mathrm{C}$. Recombinant human lipopolysaccharide-binding protein (LBP) with a C-terminal 6-His tag (R\&D Systems, Inc.) was used as a negative control protein. The wells were washed three times with $0.1 \%$ Tween 20-phosphate-buffered saline (PBS; PBST; Sigma-Aldrich) and blocked with $2 \%$ (w/v) bovine serum albumin (BSA; Sigma-Aldrich) in PBS for $2 \mathrm{~h}$ at $37^{\circ} \mathrm{C}$. Following incubation, the plate was incubated with PBS containing the 11F4 B7-H3 mAb $(1 \mu \mathrm{g} / \mu 1$, between 1:80,000 and 1:625) for $1 \mathrm{~h}$ at $37^{\circ} \mathrm{C}$. Following washing six times with PBST, the plate was incubated with HRP-conjugated goat anti-mouse IgG in $0.1 \%$ PBST-BSA buffer at $37^{\circ} \mathrm{C}$ for another $1 \mathrm{~h}$, followed by incubation with tetramethylbenzidine detection reagent (Thermo Fisher Scientific, Inc.). The reactions were terminated with $3 \mathrm{M}$ sulfuric acid (Sigma-Aldrich) and the absorbance of each sample was read at $450 \mathrm{~nm}$ on a microplate reader (Varioskan $^{\mathrm{TM}}$ Flash; Thermo Fisher Scientific, Inc.). All the groups were performed in triplicate, respectively.

Flow cytometric analysis. For flow cytometric analysis, the target cells $\left(1 \times 10^{6}\right)$ were incubated with mouse anti-human B7-H3 11F4 mAbs for $30 \mathrm{~min}$ at $37^{\circ} \mathrm{C}$ and washed with PBS. Fluorescein isothiocyanate (FITC)-labeled goat anti-mouse IgG (BD Biosciences, San Jose, CA, USA), as a secondary antibody, was added for another $30 \mathrm{~min}$ at $37^{\circ} \mathrm{C}$ at a concentration of $1 \mathrm{mg} / \mathrm{L}$. Following washing with PBS, the cells were analyzed using a flow cytometer (Cytomics FC 500, Beckman Coulter, Brea, CA, USA) and with Expo32 MultiCOMP software (Beckman Coulter).

Western blot analysis. Western blot analysis was performed to analyze the binding capacity of the $11 \mathrm{~F} 4 \mathrm{mAb}$ to the 4IgB7-H3 and 2IgB7-H3 protein on NIH3T3/4IgB7-H3 or NIH3T3/2IgB7-H3 cells, respectively. NIH3T3/mock cells were used as a negative control. The cell lysate was separated using $12 \%$ sodium dodecyl sulfate-polyacrylamide gel electrophoresis, transferred onto nitrocellulose filters and stained with 11F4 mAb. The protein bands were visualized using ECL Western Blotting Substrate (Bio-Rad Laboratories, Inc., Hercules, CA, USA).

$T$ cell proliferation. For the $\mathrm{T}$ cell proliferation assay, a 96-well flat-bottom plate was precoated with anti-CD3 $\mathrm{mAb}$ $(0.3 \mu \mathrm{g} / \mathrm{ml})$ at $4^{\circ} \mathrm{C}$ overnight. The purified $\mathrm{T}$ cells were then seeded into the wells $\left(1 \times 10^{5} /\right.$ well $)$ to co-culture with recombinant human $\operatorname{IgG}(\mathrm{hIgG}), 2 \operatorname{IgB} 7-\mathrm{H} 3$ and $4 \operatorname{IgB} 7-\mathrm{H} 3(0-8 \mu \mathrm{g} / \mathrm{ml})$, respectively. The $11 \mathrm{~F} 4 \mathrm{mAb}(10 \mu \mathrm{g} / \mathrm{ml})$ was added to the culture system, with or without anti-CD28 mAb $(1 \mu \mathrm{g} / \mathrm{ml})$. Cell Counting Kit- 8 (CCK-8) solution (16) was added to each well, and the cells were incubated at $37^{\circ} \mathrm{C}$ for another $5 \mathrm{~h}$. The absorbance was measured at $450 \mathrm{~nm}$ using a microplate reader (Thermo Fisher Scientific, Inc.). All experiments were performed in triplicate.

\section{Results}

Purified human 4IgB7-H3 and 2IgB7-H3 fusion protein. The transfected NIH3T3 cell lines secreting recombinant the $4 \mathrm{IgB} 7-\mathrm{H} 3$ and $2 \mathrm{IgB} 7-\mathrm{H} 3$ protein were successfully constructed. The supernatant was collected and purified by the C-terminal His-tag using Protino Ni-NTA Agarose. The recombinant protein was well identified by the mouse monoclonal anti-His antibody (Santa Cruz Biotechnology, Inc.; cat. no. sc-8036; Fig. 1).

Establishment of 11F4, a novel mouse anti-human B7-H3 $m A b$. The Balb/c mice were immunized with purified recombinant $4 \mathrm{IgB} 7-\mathrm{H} 3$ protein and the splenocytes were fused with murine myeloma SP2/0 cells. Following repeated screening using recombinant $4 \mathrm{IgB} 7-\mathrm{H} 3$ protein and multiple subcloning using ELISA, one hybridoma, termed 11F4, was obtained. The isotope of 11F4 was mouse IgG1 with a $\kappa$ light chain, and the hybridoma contained $>100$ chromosomes, indicating it was fusant (data not shown). Notably, 11F4 was observed to bind specifically to both the recombinant $4 \mathrm{IgB} 7-\mathrm{H} 3$ and $2 \mathrm{IgB} 7-\mathrm{H} 3$ protein (Fig. 2). In addition, the NIH3T3/4IgB7-H3 and NIH3T3/2IgB7-H3 transfectants were stained by 11F4 using flow cytometry (Fig. 3A) and western blotting (Fig. 3B).

B7-H3 protein is broadly expressed on the human tumor cell lines. The expression patterns of B7-H3 on human tumor cell lines were detected by $11 \mathrm{~F} 4$ using flow cytometry. The results demonstrated that B7-H3 was broadly and highly expressed on tumor cell lines, whereas no B7-H3 was detected was detected at had low levels on human malignant hematopoietic cell lines (Fig. 4).

2IgB7-H3 and 4IgB7-H3 signaling enhance T-lymphocyte proliferation and 11F4 inhibits this enhancement effect. The purified $\mathrm{T}$ cells were stimulated with the anti-CD3 mAb and co-cultured with recombinant hIgG, $2 \operatorname{IgB} 7-\mathrm{H} 3$ and 4IgB7-H3, respectively. The results revealed that $2 \mathrm{IgB} 7-\mathrm{H} 3$ and $4 \mathrm{IgB} 7-\mathrm{H} 3$ were able to promote T-cell proliferation, and the $11 \mathrm{~F} 4$ antibody exhibited an inhibitory effect, to a certain extent. In addition, the inhibitory effect on the $2 \mathrm{IgB} 7-\mathrm{H} 3$ group was more marked, compared with the effect on the 4IgB7-H3 group (Fig. 5A and B). In the presence of anti-human CD28 mAb, the effect on proliferation was enhanced. Notably, the inhibitory effect of $11 \mathrm{~F} 4$ was markedly increased following co-incubation with anti-CD3 $\mathrm{mAb}$, anti-CD28 $\mathrm{mAb}$ and recombinant $\mathrm{B} 7-\mathrm{H} 3$ (Fig. 5C and D).

\section{Discussion}

B7-H3 is a type I transmembrane protein belonging to the B7 superfamily $(5,9)$. B7 superfamily proteins provide stimulatory or inhibitory accessory signals for $\mathrm{T}$ cell responses. Due to exon duplication, the extracellular architecture of B7-H3 is characterized by a single $\operatorname{IgV}$-IgC-like $(2 \mathrm{IgB} 7-\mathrm{H} 3)$ or IgV-IgC-IgV-IgC-like (4IgB7-H3) domain $(8,9)$. The different roles of $2 \mathrm{IgB} 7-\mathrm{H} 3$ and $4 \mathrm{IgB} 7-\mathrm{H} 3$ in the immune system remain to be fully elucidated. In the present study, NIH3T3/4IgB7-H3 and NIH3T3/2IgB7-H3 transfectants were successfully constructed, and the two isoforms of recombinant protein were obtained (Fig. 1). In addition, a novel mAb, termed, 11F4 against human 2IgB7-H3 and 4IgB7-H3 was established (Figs. 2 and 3).

B7-H3 are ubiquitously expressed in a wide spectrum of tissues, however, its protein expression is relatively limited 


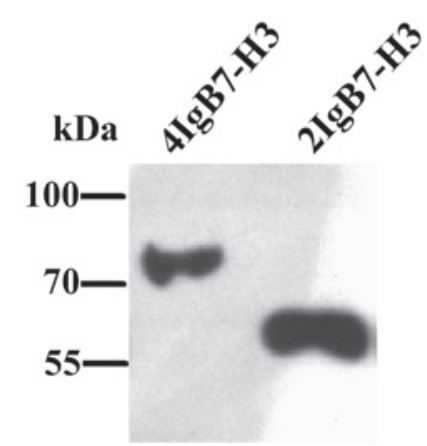

Figure 1. Detection of purified human 4IgB7-H3 and $2 \operatorname{IgB} 7-\mathrm{H} 3$ proteins using mouse monoclonal anti-His antibody. The recombinant 4IgB7-H3 and $2 \mathrm{IgB} 7-\mathrm{H} 3$ proteins were purified from the concentrated supernatant of transfectants using Protino Ni-NTA Agarose. The recombinant proteins were separated using $12 \%$ sodium dodecyl sulfate-polyacrylamide gel electrophoresis in reducing conditions, followed by western blotting with anti-His antibody. Horseradish peroxidase-conjugated goat anti-mouse IgG was used as a secondary antibody. The blot shown is representative of three independent experiments.

and maintained at low levels. The mRNA transcription of B7-H3 is inconsistent with its protein expression, suggesting the existence of a complex post-transcriptional regulatory mechanism. In addition, the expression of B7-H3 has been described in malignancies, including glioma, and lung, pancreatic, ovarian, breast, gastric and colon cancer (17-22). However, a correlation between the expression of B7-H3 on cancer cells and pathological results remains to be fully elucidated. In the present study, using the 11F4 mAb, high expression levels of B7-H3 were broadly expressed on tumor cell lines at the protein level. Normal cell lines, including HEK-293 and EAhy926 cell lines also exhibited high expression levels of B7-H3. Notably, B7-H3 was not be detected on several human malignant hematopoietic cell lines, including U266, Jutkat, Daudi and Raji cells, while PRMI-8226, HL-60, U937 and K562 cells were observed to exhibit low or moderate expression levels of B7-H3 (Fig. 4), similar to previously reported observations $(23,24)$. It has been reported that the majority of these tumor cell lines express $4 \operatorname{IgB} 7-\mathrm{H} 3$, rather than $2 \operatorname{IgB} 7-\mathrm{H} 3(24)$.

As with other members of the B7 family, B7-H3 is important in costimulatory pathways in $\mathrm{T}$ cells. However, the function of B7-H3 remains controversial. Chapoval et al reported that $\mathrm{B} 7-\mathrm{H} 3$ costimulates the proliferation of $\mathrm{CD} 4{ }^{+}$ and $\mathrm{CD}^{+} \mathrm{T}$ cells, enhances the induction of cytotoxic $\mathrm{T}$ cells and selectively stimulates IFN- $\gamma$ production in the presence of $\mathrm{T}$ cell receptor signaling (5). Other reports have indicated that B7-H3, with its two isoforms of $2 \operatorname{IgB} 7-\mathrm{H} 3$ and 4IgB7-H3, may have a similar inhibitory function $(10,11)$. In the $\mathrm{T}$ cell proliferation assay performed in the present study, the biological functions of these two isoforms were found to be similar, positive regulating the $\mathrm{T}$ cells. The $11 \mathrm{~F} 4 \mathrm{mAb}$ effectively inhibited the B7-H3 signal, resulting in inhibition of $\mathrm{T}$ cell proliferation.

In conclusion, the present study successfully generated a novel specific mouse anti-human B7-H3 mAb (11F4), with the ability to recognize $4 \operatorname{IgB} 7-\mathrm{H} 3$ and $2 \operatorname{IgB} 7-\mathrm{H} 3$. Using this $\mathrm{mAb}$, high expression levels of $\mathrm{B} 7-\mathrm{H} 3$ were observed in tumor cells, as in previous reports. The recombinant $4 \operatorname{IgB} 7-\mathrm{H} 3$ and

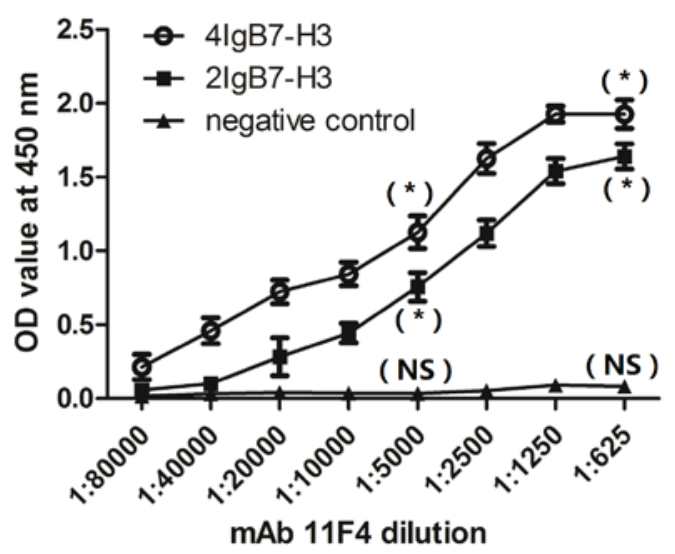

Figure 2. Comparison of the binding activity of the 11F4 anti-B7-H3 mAb to purified human $4 \operatorname{IgB} 7-\mathrm{H} 3$ and $2 \operatorname{IgB} 7-\mathrm{H} 3$ proteins. Purified $4 \operatorname{IgB} 7-\mathrm{H} 3$ and $2 \mathrm{IgB} 7-\mathrm{H} 3$ proteins $(10 \mu \mathrm{g} / \mathrm{ml} ; 100 \mu \mathrm{l} /$ well $)$ were coated on a 96 -well plate overnight at $4^{\circ} \mathrm{C}$, respectively. Recombinant human lipopolysaccharide-binding protein with a C-terminal 6 -His tag was used as a negative control protein. Following blocking with $2 \%$ bovine serum albumin in PBS, the plate was incubated with PBS containing the $11 \mathrm{~F} 4 \mathrm{~B} 7-\mathrm{H} 3 \mathrm{mAb}$ $(1 \mu \mathrm{g} / \mu 1,1: 80,000-1: 625)$ for $1 \mathrm{~h}$ at $37^{\circ} \mathrm{C}$. Horseradish peroxidase-conjugated goat anti-mouse IgG was used as the second antibody. Finally, the plate was incubated with tetramethylbenzidine and terminated with $3 \mathrm{M}$ sulfuric acid. The absorbance of each sample was read at $450 \mathrm{~nm}$. All the experiments were performed in triplicate. Incubation with $11 \mathrm{~F} 4 \mathrm{~B} 7-\mathrm{H} 3 \mathrm{mAb}$ at 1:5,000 and 1:625 was statistically compared with incubation at 1:80,000. Values are expressed as the mean \pm standard error of the mean $(n=3) .{ }^{*} \mathrm{P}<0.001$. NS, not significant; PBS, phosphate-buffered saline; $\mathrm{mAB}$, monoclonal antibody; OD, optical density.
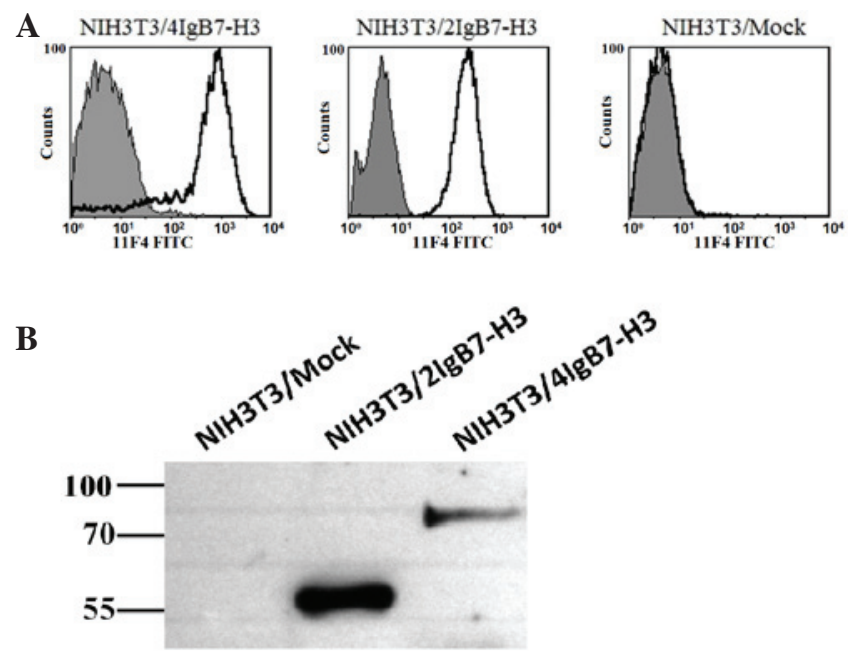

Figure 3. Reactivity of the $11 \mathrm{~F} 4 \mathrm{mAb}$ with transfectants of B7-H3. (A) 4IgB7-H3, 2IgB7-H3 and Mock cell lines (5x105 cells/well) were stained with 11F4 anti-B7-H3 antibodies (white peak) or negative control mouse IgG (gray peak) at room temperature for $30 \mathrm{~min}$, followed by fluorescein isothiocyanate-goat anti-mouse IgG. The results are representative of one of three experiments. (B) Cell lysate of 4IgB7-H3, 2IgB7-H3 or Mock cell lines loaded onto $12 \%$ SDS-PAGE, transferred onto nitrocellulose filters and stained with 11F4 mAb, followed by incubation with horseradish peroxidase-conjugated goat anti-mouse $\mathrm{IgG}$. The bands were visualized by chemiluminescence. The results are representative of one of three experiments. mAB, monoclonal antibody.

2Ig-B7-H3 proteins enhanced T cell proliferation, and the effect of $\mathrm{B} 7-\mathrm{H} 3$ on the promotion of $\mathrm{T}$ cell proliferation was 

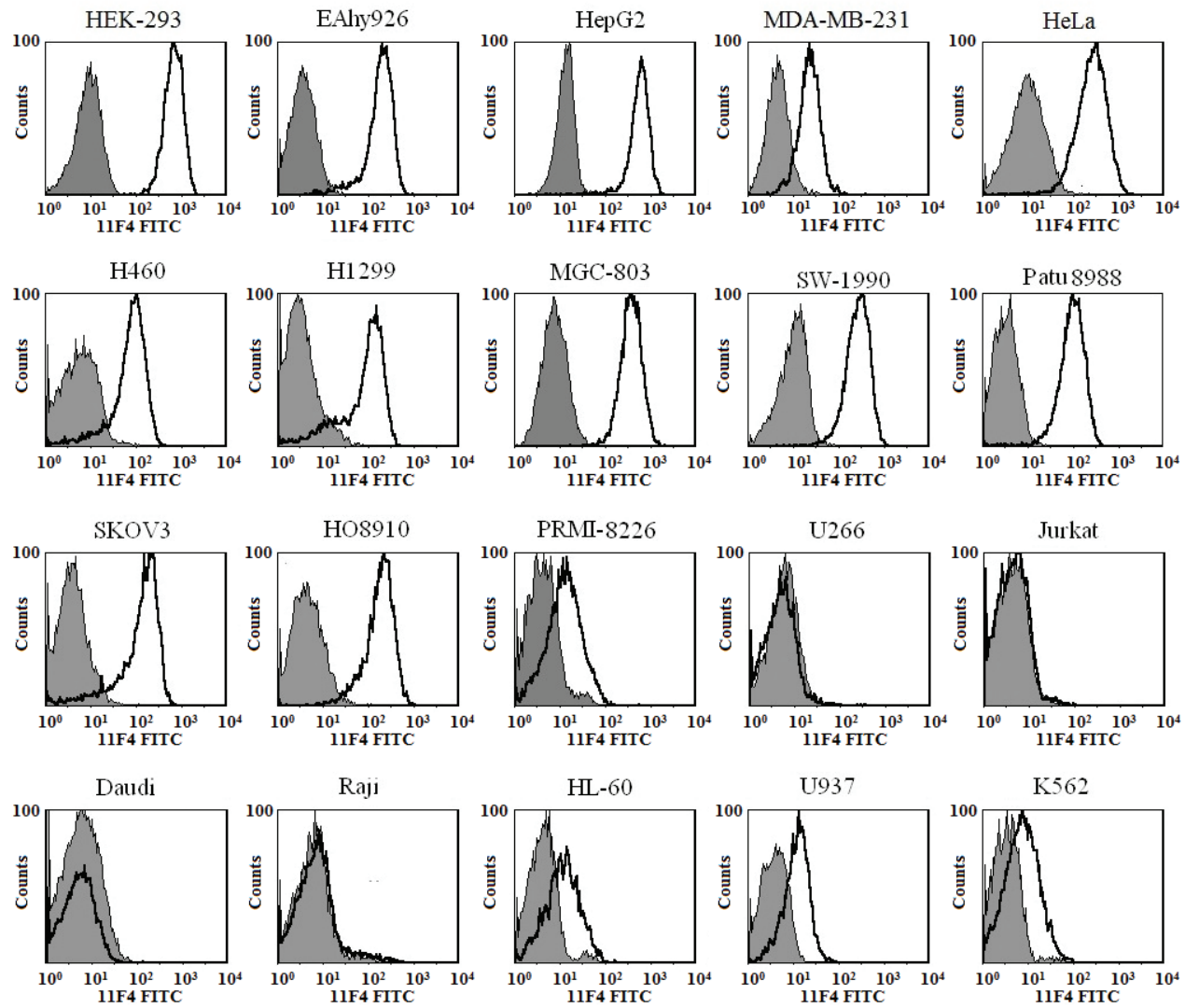

Figure 4. Expression of B7-H3 antigen on different cell lines, determined using 11F4. Different cell lines were stained with 11F4 (white peak) or negative control mouse IgG (grey peak) at room temperature for $30 \mathrm{~min}$, followed by incubation with goat anti-mouse IgG-fluorescein isothiocyanate. The data show the results of flow cytometric analysis.

A

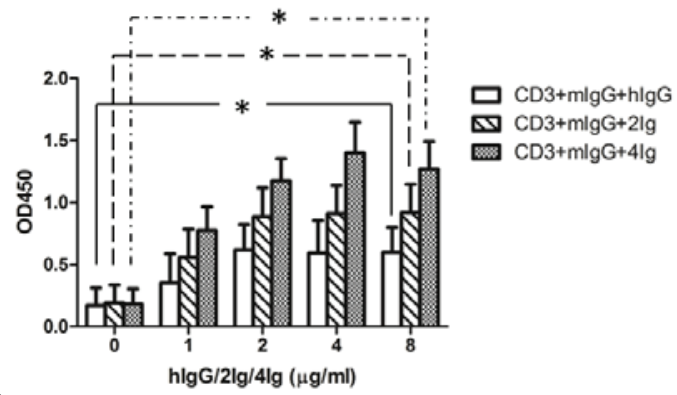

C

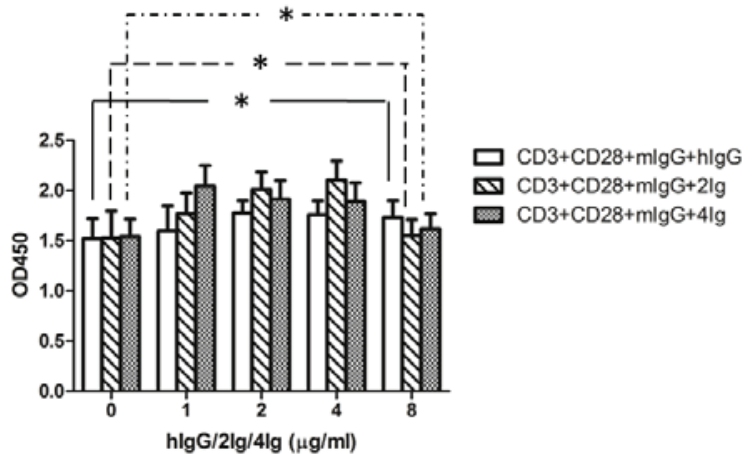

B

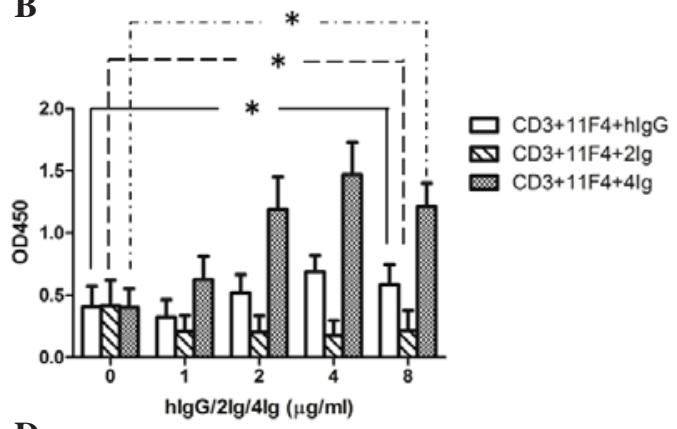

D

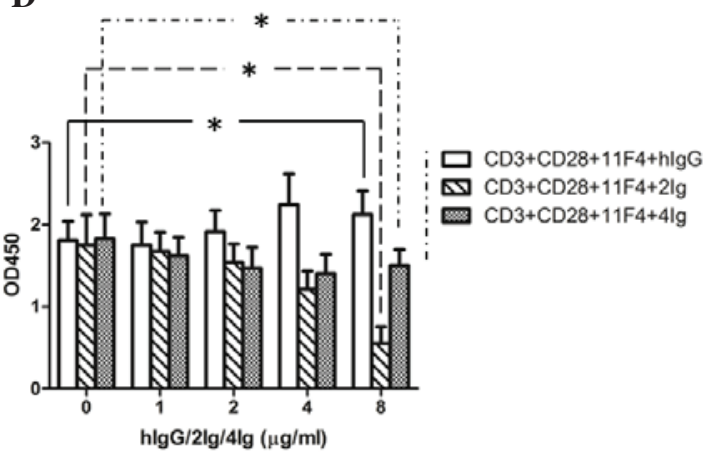

Figure 5. T cell proliferation. A 96-well flat-bottom plate was coated with anti-CD3 $\mathrm{mAb}(0.3 \mu \mathrm{g} / \mathrm{ml})$ at $4{ }^{\circ} \mathrm{C}$ overnight, following which the purified $\mathrm{T}$ cells were seeded into wells $\left(1 \times 10^{5} /\right.$ well) and co-cultured with recombinant $\mathrm{h} \operatorname{IgG}, 2 \operatorname{IgB} 7-\mathrm{H} 3(2 \operatorname{Ig})$ and $4 \operatorname{IgB} 7-\mathrm{H} 3(4 \mathrm{Ig})$ at $0-8 \mu \mathrm{g} / \mathrm{ml}$, respectively. Meanwhile, (A) mIgG $(10 \mu \mathrm{g} / \mathrm{ml})$ was added to the culture system without anti-CD28 mAb; (B) $11 \mathrm{~F} 4 \mathrm{mAb}(10 \mu \mathrm{g} / \mathrm{ml})$ was added to the culture system without anti-CD28 mAb; (C) $\mathrm{mIgG}$ $(10 \mu \mathrm{g} / \mathrm{ml})$ was added to the culture system with anti-CD28 mAb $(1 \mu \mathrm{g} / \mathrm{ml}) ;(D) 11 \mathrm{~F} 4 \mathrm{mAb}(10 \mu \mathrm{g} / \mathrm{ml})$ was added to the culture system with anti-CD28 mAb $(1 \mu \mathrm{g} / \mathrm{ml})$. Cell Counting Kit-8 solution was added to each well and incubated at $37^{\circ} \mathrm{C}$ for $5 \mathrm{~h}$. The absorbance was measured at $450 \mathrm{~nm}$. All the experiments were performed in triplicate and values are expressed as the mean \pm standard error of the mean ( $\mathrm{n}=3)$. Incubation with $\mathrm{hIgG} / 2 \mathrm{Ig} / 4 \mathrm{Ig}(8 \mu \mathrm{g} / \mathrm{ml}) \mathrm{were}$ statistically compared with those not incubated, ${ }^{*} \mathrm{P}<0.01$. hIgG, human IgG; mAb/m, monoclonal antibody; OD, optical density. 
further verified using 11F4 in an inhibitory assay. The role of 4IgB7-H3 and 2Ig-B7-H3 on accessory signals in T cell functions, and whether the two isoforms have different receptors, requires further investigation.

\section{References}

1. Chen W, Hou Z, Li C, Xiong S and Liu H: Cloning and characterization of porcine 4Ig-B7-H3: a potent inhibitor of porcine T-cell activation. PLoS One 6: e21341, 2011.

2. Latchman Y, Wood CR, Chernova T, Chaudhary D, Borde M, Chernova I, Iwai Y, Long AJ, Brown JA, Nunes R, et al: PD-L2 is a second ligand for PD-1 and inhibits T cell activation. Nat Immunol 2: 261-268, 2001.

3. Selenko-Gebauer N, Majdic O, Szekeres A, Höfler G, Guthann E, Korthäuer U, Zlabinger G, Steinberger P, Pickl WF, Stockinger H, et al: B7-H1 (programmed death-1 ligand) on dendritic cells is involved in the induction and maintenance of $\mathrm{T}$ cell anergy. J Immunol 170: 3637-3644, 2003.

4. Dong C, Juedes AE, Temann UA, Shresta S, Allison JP, Ruddle NH and Flavell RA: ICOS co-stimulatory receptor is essential for T-cell activation and function. Nature 409: 97-101, 2001.

5. Chapoval AI, Ni J, Lau JS, Wilcox RA, Flies DB, Liu D, Dong H, Sica GL, Zhu G, Tamada K and Chen L: B7-H3: A costimulatory molecule for $\mathrm{T}$ cell activation and IFN-gamma production. Nat Immunol 2: 269-274, 2001.

6. Sica GL, Choi IH, Zhu G, Tamada K, Wang SD, Tamura H, Chapoval AI, Flies DB, Bajorath J and Chen L: B7-H4, a molecule of the $\mathrm{B} 7$ family, negatively regulates $\mathrm{T}$ cell immunity. Immunity 18: 849-861, 2003.

7. Tafuri A, Shahinian A, Bladt F, Yoshinaga SK, Jordana M, Wakeham A, Boucher LM, Bouchard D, Chan VS, Duncan G, et al: ICOS is essential for effective T-helper-cell responses. Nature 409: 105-109, 2001.

8. Steinberger P, Majdic O, Derdak SV, Pfistershammer K, Kirchberger S, Klauser C, Zlabinger G, Pickl WF, Stöckl J and Knapp W: Molecular characterization of human 4Ig-B7-H3, a member of the B7 family with four Ig-like domains. J Immunol 172: 2352-2359, 2004.

9. Sun M, Richards S, Prasad DV, Mai XM, Rudensky A and Dong C: Characterization of mouse and human B7-H3 genes. J Immunol 168: 6294-6297, 2002.

10. Ling V, Wu PW, Spaulding V, Kieleczawa J, Luxenberg D, Carreno BM and Collins M: Duplication of primate and rodent B7-H3 immunoglobulin V- and C-like domains: Divergent history of functional redundancy and exon loss. Genomics 82: 365-377, 2003.

11. Suh WK, Gajewska BU, Okada H, Gronski MA, Bertram EM, Dawicki W, Duncan GS, Bukczynski J, Plyte S, Elia A, et al: The B7 family member B7-H3 preferentially down-regulates T helper type 1-mediated immune responses. Nat Immunol 4: 899-906, 2003.
12. Indiveri F, Huddlestone J, Pellegrino MA and Ferrone S: Isolation of human T lymphocytes: Comparison between nylon wool filtration and rosetting with neuraminidase (VCN) and 2-aminoethylisothiouronium bromide (AET)-treated sheep red blood cells (SRBC). J Immunol Methods 34: 107-115, 1980.

13. Madsen M, Johnsen HE, Hansen PW and Christiansen SE: Isolation of human $\mathrm{T}$ and $\mathrm{B}$ lymphocytes by E-rosette gradient centrifugation. Characterization of the isolated subpopulations. J Immunol Methods 33: 323-336, 1980.

14. Shapiro J, Sciaky N, Lee J, Bosshart H, Angeletti RH and Bonifacino JS: Localization of endogenous furin in cultured cell lines. J Histochem Cytochem 45: 3-12, 1997.

15. de StGroth SF and Scheidegger D: Production of monoclonal antibodies: Strategy and tactics. J Immunol Methods 35: 1-21, 1980.

16. Ishiyama M, Miyazono Y, Sasamoto K, Ohkura Y and Ueno K: A highly water-soluble disulfonated tetrazolium salt as a chromogenic indicator for NADH as well as cell viability. Talanta 44: 1299-1305, 1997.

17. Zhou Z, Luther N, Ibrahim GM, Hawkins C, Vibhakar R, Handler MH and Souweidane MM: B7-H3, a potential therapeutic target, is expressed in diffuse intrinsic pontine glioma. J Neurooncol 111: 257-264, 2013.

18. Boland JM, Kwon ED, Harrington SM, Wampfler JA, Tang H, Yang $\mathrm{P}$ and Aubry MC: Tumor B7-H1 and B7-H3 expression in squamous cell carcinoma of the lung. Clin Lung Cancer 14: 157-163, 2013.

19. Fauci JM, Sabbatino F, Wang Y, Londoño-Joshi AI, Straughn JM Jr, Landen CN, Ferrone S and Buchsbaum DJ: Monoclonal antibody-based immunotherapy of ovarian cancer: Targeting ovarian cancer cells with the B7-H3-specific mAb 376.96. Gynecol Oncol 132: 203-210, 2014.

20. Arigami T, Narita N, Mizuno R, Nguyen L, Ye X, Chung A, Giuliano AE and Hoon DS: B7-h3 ligand expression by primary breast cancer and associated with regional nodal metastasis. Ann Surg 252: 1044-1051, 2010.

21. Wu CP, Jiang JT, Tan M, Zhu YB, Ji M, Xu KF, Zhao JM, Zhang GB and Zhang XG: Relationship between co-stimulatory molecule B7-H3 expression and gastric carcinoma histology and prognosis. World J Gastroenterol 12: 457-459, 2006.

22. Sun J, Chen LJ, Zhang GB, Jiang JT, Zhu M, Tan Y, Wang HT, Lu BF and Zhang XG: Clinical significance and regulation of the costimulatory molecule B7-H3 in human colorectal carcinoma. Cancer Immunol Immunother 59: 1163-1171, 2010.

23. Castriconi R, Dondero A, Augugliaro R, Cantoni C, Carnemolla B, Sementa AR, Negri F, Conte R, Corrias MV, Moretta L, et al: Identification of $4 \mathrm{Ig}-\mathrm{B} 7-\mathrm{H} 3$ as a neuroblastoma-associated molecule that exerts a protective role from an NK cell-mediated lysis. Proc Natl Acad Sci U S A 101: 12640-12645, 2004.

24. Zhou YH, Chen YJ, Ma ZY, Xu L, Wang Q, Zhang GB, Xie F, Ge Y, Wang XF and Zhang XG: 4IgB7-H3 is the major isoform expressed on immunocytes as well as malignant cells. Tissue Antigens 70: 96-104, 2007. 